\title{
NORMOLIPEMIC ISOLATED XANTHOMA
}

Gowri Sankar R¹, Prem Charles², Rehana Tippoo³, P. Viswanathan4, B. Krishnaswamy ${ }^{5}$

\section{HOW TO CITE THIS ARTICLE:}

Gowri Sankar R, Prem Charles, Rehana Tippoo, P Viswanathan, B Krishnaswamy. "Normolipemic isolated xanthoma". Journal of Evolution of Medical and Dental Sciences 2013; Vol. 2, Issue 42, October 21; Page: 80218024.

ABSTRACT: Xanthomas are often a manifestation of underlying lipid abnormalities.A 17-year-old female presented to our hospital with pain and swelling over the left knee joint.Routine investigations and lipid profile were normal. Dermatological examination and Psychiatric examination were done and found to be normal. Histopathology from the lesion revealed macrophages and Touton type of giant cells. We present a case of normolipemic isolated xanthoma, which not only is an an uncommon occurrence but also needs a regular follow up because a high association with reticuloendothelial malignancies has also been reported.

KEYWORDS: Isolated xanthoma,Knee joint,Reticuloendothelial malignancy

INTRODUCTION: Isolated xanthomas as such involving major joint is uncommon, in the setting of normal biochemical profile.Different classifications of plain xanthomas have been presented. Generally, they can be divided into two groups: 1) plain xanthomas with increased serum levels of lipids, and 2) plain xanthomas with normal serum levels of lipids. The second group can be, in its turn, subdivided into three types: 1) idiopathic; II) associated with multiple myeloma, monoclonal gammopathies, and, less frequently, with lymphoproliferative disorders, and III) associated with abnormalities in the structure and content of lipoproteins. ${ }^{1}$

In approximately half of the cases, they occur in the absence of hyperlipidemia and hypercholesterolemia. ${ }^{2}$

CASE REPORT: A 17 year old female developed pain and swelling over the left knee joint allegedly after an episode of trauma one yearbackafter which she took native treatment and analgesics and pain subsided.Three months back the pain and swelling reappeared.The patient had restriction of movements in the left knee which interfered with her daily activities like sitting,squatting and sitting cross legged.There was no history of tuberculosis .

On examination patient had swelling over the left knee which was doughy in consistency,tender on palpation.Flexion deformity of 40 degrees and antalgic gait present.Patient did not have any neurological deficit or any tell-tale sign of tuberous sclerosis.

X-ray showed no bony abnormality.

Lipid profile was done for the patient and was found to be un remarkable.

Subtotal or Partial synovectomy was done and specimen sent for Histo-pathological examination.

Patient had difficulty in walking post-operatively and recovered subsequently.

Macroscopy revealed grey white yellow colored soft tissue piece measuring 5 x 4 x $2 \mathrm{~cm}$.

Microscopy shows fibrocollagenous soft tissue containing numerous macrophages,few inflammatory giant cells (Fig 2) and occasional Touton type of giant cells (Fig 4).There was 


\section{CASE REPORT}

formation of vascular granulation tissueThe entire tissue was infiltrated with inflammatory cells predominantly of chronic type (Fig 1). Features were consistent with Xanthoma.

DISCUSSION: Xanthoma is a localized collection of tissue histiocytes containing lipid ${ }^{3}$ in which the patient usually presents with alteration in serum lipid. It is not a true tumor but rather a reactive histiocyte proliferation that occurs in response to alterations in serum lipids. Xanthomas may develop in most primary and some secondary (primary biliary cirrhosis, Diabetes mellitus) hyperlipoproteinemias and occasionally in normolipemic state. Usually xanthomas occur in the skin and subcutis, ${ }^{4}$ but occasionally they involve deep soft tissue such as tendons (xanthoma of the tendon sheath) ${ }^{5}$ or synovium ${ }^{6}$ (Fig 3) Xanthelasmas are xanthomas of the eye lid and usually observed in normolipemic persons.

Tuberous xanthoma are large plaque like lesions of the subcutis usually located on the buttocks, elbows, knees and fingers and seen with type IIa or III hyperlipoproteinemia.It contains large amounts of cholesterol and its esters, which may be demonstrated under polarized light in fresh tissue as birefringent crystals.

Deep xanthomas occur most frequently in tendon ${ }^{5}$ or synovium 6 and rarely bone. ${ }^{7}$ Usually the severity of the xanthoma is roughly proportional to the severity and duration of the increased cholesterol levels.

Tuberous and Tendinous Xanthomas are essentially identical. In their early stages they may contain some non-foamy histiocytes interspersed with occasional inflammatory cells. The histiocytes are bland with small pyknotic nuclei. Some cells may contain fine granules of hemosiderin. Collections of extracellular cholesterol (cholesterol clefts) flanked by giant cells are conspicuous. Varying amounts of fibrosis may be present but are most marked in long standing lesion. Ultra structurally, xanthoma cells of all of these lesions are similar and contain numerous clear vacuoles, presumably representing cholesterol or its esters. ${ }^{8}$

Tuberous xanthomas have regressed on medical therapy alone. ${ }^{9}$ Lipid in them is derived from blood ${ }^{1}$.The fibrosis characteristic of mature or long standing xanthomas is believed to be related to the fibrogenic properties of extracellular cholesterol.10

Differential diagnosis includes:

Alpha mannosidase deficiency: Here the patient presents with neurological deficit and do not thrive beyond 15years.Also there is histological proliferation of synovial tissue.

Tuberous Xanthoma: Here the patients have mental retardation with stigma on the skin presenting as plaques along with hyperlipidemia.

\section{REFERENCES:}

1. Daoud MS, Lust JA, Kyle RA, Pittelkow MR. Monoclonal gammopathies and associated skin disorders. J Am Acad Dermatol. 1999; 40:507-35.

2. Maxit MJ, Paz RA. Xantomaplanodifuso com arthritis, Serositis, eritemanodoso, vasculitis y leucemiamielomonocitica. Medicina (B Aires). 2001; 61:187-90.

3. Adams CWM, Bayliss LB, Ibrahim MZM, etal. Phospholipids in atherosclerosis: the modification of the cholesterol granuloma by phospholipid. J Pathol Bacteriol1963; 86:43.

4. Beerman H. Lipid diseases as manifested in the skin. Medclin North Am 1951; 35:433. 
5. Cristol DS, Gill AB. Xanthoma of tendon sheath. JAMA 1943; 122: 1013.

6. DeSanto DA, Wilson PD. Xanthomatous tumors of joints. J Bone Joint Surg1939; 21:53.

7. Hamilton WC, Ramsey PL, Hanson SM, et al. Osseous xanthoma and multiple hand tumors as a complication of hyperlipidemia. J Bone Joint Surg Am1975; 57:551.

8. Anderson DR. Ultrastructure of xanthelasma. Arch ophthalmol1969; 81:692.

9. Buxtorf JC, Beaumont V, Jacotot B, et al. Regression de xanthomeset medicaments hypolipidemiants. Atherosclerosis1974; 19:1.

10. Zelger B, Ceiro R, Soyer HP, et al. Reticulohistiocytoma and multicentricreticulocytosis: histopathologic and immuno phenotypic distinct entities. Am J Dermatopathol, 1994; 16: 577.

\section{MACROSCOPIC PICTURES}



Specimen which is grey white



On c/s yellow red colored areas seen

\section{MICROSCOPIC PICTURES : H \&E SECTIONS}
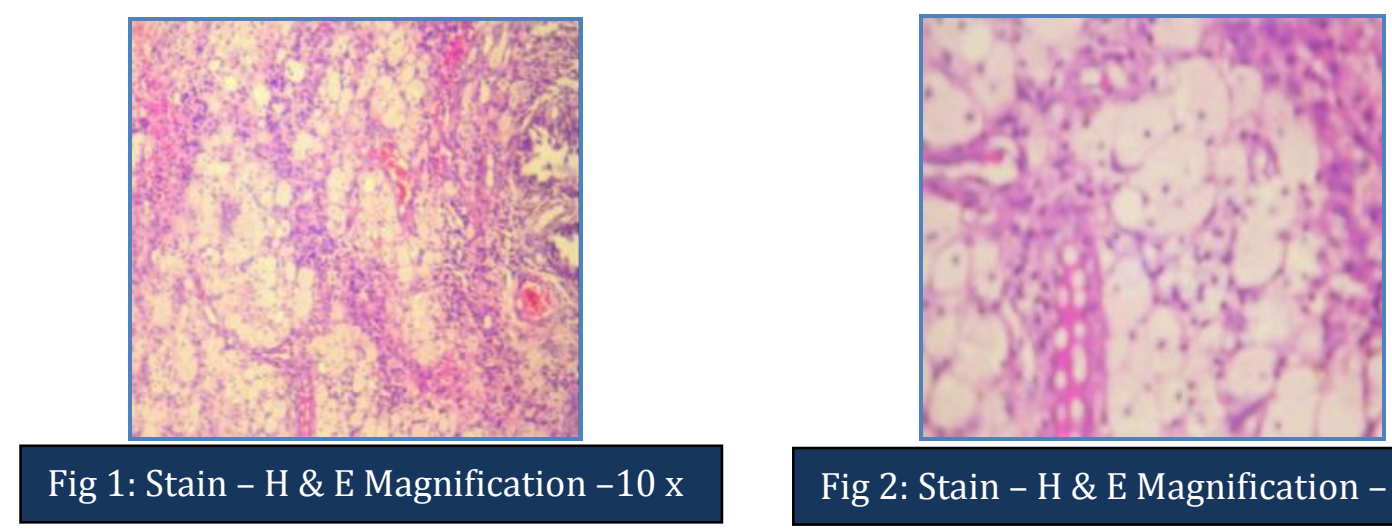

Fig 2: Stain - H \& E Magnification - $20 \mathrm{x}$

Xanthoma cells can be visualised along with inflammatory cells and congested blood vessels involving the synovium. 




Fig 3: Stain-H \& E Magnification-10x

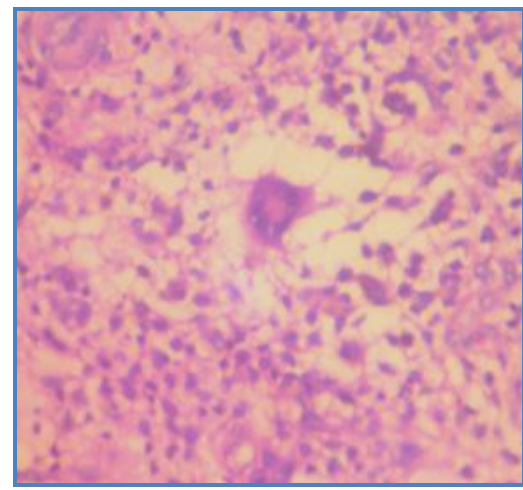

Fig 4: Stain-H \& E Magnification-20x

Synovial lining containing xanthoma cells and Touton type of cells along with lymphocytic infiltrate.

\section{AUTHORS:}

1. Gowri Sankar. R

2. D. Prem Charles

3. Rehana Tippoo

4. P. Viswanathan

5. B. Krishnaswamy

\section{PARTICULARS OF CONTRIBUTORS:}

1. $2^{\text {nd }}$ Year Post Graduate, Department of Pathology, Rajah Muthiah Medical College, Annamalai University.

2. $1^{\text {st }}$ Year Post Graduate, Department of Pathology, Rajah Muthiah Medical College, Annamalai University.

3. Professor, Department of Pathology, Rajah Muthiah Medical College, Annamalai University.
4. Professor, Department of Pathology, Rajah Muthiah Medical College, Annamalai University.

5. Professor, Department of Pathology, Rajah Muthiah Medical College, Annamalai University.

\section{NAME ADDRESS EMAIL ID OF THE CORRESPONDING AUTHOR:}

Dr. P. Viswanathan,

Professor, Department of Pathology,

Faculty of Medicine,

Rajah Muthiah Medical College,

Annamalai University, Chidambaram,

Tamilnadu, India, PIN - 608002.

Email -drpviswanathan2013@gmail.com

Date of Submission: 02/08/2013.

Date of Peer Review: 03/08/2013.

Date of Acceptance: 01/10/2013.

Date of Publishing: 15/10/2013 